\title{
ПРОВЕДЕННЯ НЕГЛАСНИХ СЛІДЧИХ ДІЙ: ОСОБЛИВОСТІ ПРАВОВОГО РЕГУЛЮВАННЯ
}

Скрябін О. М.

у статті визначена сутність негласних слідчих дій; уточнена особливість таких дій, яка полягає в тому, що відомості щодо факту та методів реалізації негласних слідчих дій не можуть бути розголошені. Негласні слідчі дії реалізуються тільки в разі крайньої необхідності, якщо відомості про кримінальне правопорушення та людину, яка його скоїла, отримати іншим способом неможливо. Виявлено, що недосконалість законодавства у сфері правового регулювання негласних слідчих дій полягає в тому, що в процесі запровадження негласних форм кримінально-процесуальної діяльності законодавець у Кримінальному процесуальному кодексі певною мірою продублював положення Закону України «Про оперативно-розшукову діяльність», внаслідок чого стали існувати схожі за гносеологічною природою два різновиди негласних заходів отримання інформації: негласні слідчі діi та оперативно-розшукова діяльність. $\epsilon$ два підходи до виділення підстав реалізації негласних слідчих дій. Відповідно до першого виділяють юридичні та фактичні підстави. Згідно з другим підходом виділяють матеріально-правові, процесуальні й фактичні підстави реалізації негласних слідчих дій. Матеріально-правова підстава реалізаціі негласних слідчих дій - це ступінь тяжкості кримінального правопорушення, щодо якого здійснюється розслідування в рамках конкретного кримінального провадження. Процесуальна підстава реалізації негласних слідчих дій - це рішення, яке приймається суб'єктом кримінального провадження в рамках його компетенції. Фактична підстава проведення негласних слідчих дій - це відомості, які підтверджують реальну можливість отримати внаслідок їх реалізації докази, що мають значення для кримінального провадження. Відповідно до чинного законодавства, негласні слідчі діі регламентуються без необхідної логічності та системності. Така ситуація призводить до штучної конкуренції норм права, а деякі інститути негласних слідчих дій не отримали нині досконалої та необхідної процесуальної форми, яка $\sigma$ могла слугувати достатньою гарантією для отримання достовірних та надійних доказів і належного захисту прав і свобод людини.

Ключові слова: негласні слідчі діі, правове регулювання, кримінальний процесуальний кодекс, слідчий, прокурор, підстави.
Skriabin 0 . M. Conducting silent investigative actions: features of legal regulation

The article defines the essence of covert investigative actions; specified feature of such actions, which is that information about the fact and methods of covert investigative actions can not be disclosed. Undercover investigative actions are carried out only in case of extreme necessity, if it is impossible to obtain information about the criminal offense and the person who committed it in another way. It was revealed that the imperfection of the legislation in the field of legal regulation of covert investigative actions is that when introducing covert forms of criminal procedure, the legislator in the Criminal Procedure Code to some extent duplicated the provisions of the Law of Ukraine "On operational and investigative activities". two types of covert measures of obtaining information are similar in epistemological nature: covert investigative actions and operative-search activities. There are two approaches to identifying the grounds for covert investigative actions. According to the first, there are legal and factual grounds. According to the second approach, there are substantive, procedural and factual grounds for the implementation of covert investigative actions. The material and legal basis for the implementation of covert investigative actions is the severity of the criminal offense, which is being investigated in a particular criminal proceeding. Procedural basis for covert investigative actions is a decision made by a subject of criminal proceedings within its competence. The actual basis for covert investigative actions is information that confirms the real possibility of obtaining evidence relevant to criminal proceedings as a result of their implementation. According to the current legislation, covert investigative actions are regulated without the necessary logic and system. This situation leads to artificial competition between the rule of law, and some institutions of covert investigative actions have not received a perfect and necessary procedural form that could serve as a sufficient guarantee for obtaining reliable and reliable evidence and proper protection of human rights and freedoms.

Key words: covert investigative actions, legal regulation, criminal procedure code, investigator, prosecutor, grounds.

() Скрябін О. М., 2020 
Постановка проблеми та іï актуальність. Негласні слідчі дії мають особливий статус у системі засобів доказування в кримінальному провадженні. В Україні інститут негласних слідчих дій з'явився після внесення істотних змін у Кримінально-процесуальний кодекс України [1] в 2012 році. Проведення негласних слідчих дій у процесі досудового розслідування досить тісно пов'язане із ст. 31 та 32 Конституції України [2], в яких гарантується право громадян на таємницю листування, приватне особисте, сімейне життя та спілкування. У процесі реалізації негласних слідчих дій зазначені права українських громадян обмежуються певною мірою, що передбачено законодавством. Особливістю негласних слідчих дій $\epsilon$ те, що вони одночасно виступають ефективним джерелом отримування доказової інформації, а також можуть бути засобом порушення прав, інтересів та свобод громадян. Така особливість негласних слідчих дій та новизна вказаного інституту зумовлюють важливість та необхідність дослідження правового регулювання проведення негласних слідчих дій.

Аналіз останніх досліджень і публікацій. Дослідженню проблематики проведення негласних слідчих дій, їх правового регулювання, використання відомостей, отриманих у результаті реалізації негласних слідчих дій присвячені роботи таких авторів, як Ю.М. Грошевий [3], В.А. Колесник [4], Ю.В. Меркулова [5], Ю.М. Мирошниченко [6], А.Б. Сергєєва [7], А.В. Шило [8]. Проте варто зазначити, що необхідною $\epsilon$ актуалізація та удосконалення знань щодо дослідження правового регулювання реалізації негласних слідчих дій, що пов'язано із суспільними змінами, які впливають на проведення досудового розслідування.

Метою статті $\epsilon$ аналіз та дослідження особливостей правового аспекту проведення негласних слідчих дій.

Виклад основного матеріалу. Відповідно до ст. 246 Кримінального процесуального кодексу України (далі - КПК), «негласні слідчі дії - це різновид слідчих дій, відомості про факт та методи проведення яких не підлягають розголошенню, спрямовані на збирання, перевірку чи дослідження фактичних даних у конкретному кримінальному провадженні та які проводяться у випадках крайньої потреби, коли відомості про злочин та особу, яка його вчинила, неможливо отримати в інший спосіб» [1]. В.А. Колесник зазначає, що рішення про їх проведення приймає слідчий, прокурор, а в передбачених законом випадках - слід- чий суддя за клопотанням прокурора або за клопотанням слідчого, погодженого з прокурором. У цьому аспекті варто зазначити, що у випадку зі слідчим суддею йдеться, звичайно, про процесуальні рішення, якими він санкціонує спрямовані на ефективне збирання доказової інформації тактичні рішення слідчого (прокурора), постановляючи ухвалу про дозвіл на проведення негласних слідчих дій [9].

Досліджуючи окремі аспекти регулювання інституту негласних слідчих дій у чинному законодавстві України з позиції їх практичного застосування, І.В. Іваненко стверджує, що КПК України до суб'єктів, які мають право ініціювати клопотання про проведення негласних слідчих дій, зараховує слідчого і прокурора, тоді як Закон України «Про оперативно-розшукову діяльність» додає до цього переліку також керівника оперативного підрозділу або його заступника, які можуть подати відповідне клопотання, узгодивши його з відповідним прокурором [10, с. 67].

Досліджуючи правове регулювання проведення негласних слідчих дій, А.В. Шило говорить про недосконалість законодавства, яка проявляється і в тому, що, запроваджуючи негласні форми кримінальної процесуальної діяльності, законодавець у КПК значною мірою продублював положення Закону України «Про оперативно-розшукову діяльність», наслідком чого стало існування тотожних за гносеологічною природою двох різновидів негласних заходів отримання інформації: негласних слідчих дій та оперативно-розшукової діяльності. При цьому, з огляду на те, що КПК передбачає змогу під час досудового розслідування здійснювати лише негласні слідчі дії, подальшого наукового дослідження потребує правовий порядок їх проведення відповідно до засад кримінального провадження [8, с. 30].

Традиційно в доктрині кримінального права прийнято виділяти юридичні та фактичні підстави для проведення негласних слідчих дій. Так, Д.Б. Сергєєва виділяє два аспекти юридичних підстав для реалізації негласних слідчих дій - широкий та вузький. У широкому аспекті під юридичною (правовою) підставою варто розуміти наявність законодавчих норм, що регламентують (передбачають) можливість проведення тієї чи іншої процесуальної дії. У вузькому розумінні юридичною підставою $\epsilon$ складений відповідно до встановлених законом вимог процесуальний документ, що надає певному суб'єкту право здійснювати ту чи іншу процесуальну дію [7]. До фактичних підстав авторка 
зараховує наявність у матеріалах кримінального провадження достатніх відомостей, що свідчать про можливість досягнення мети відповідної процесуальної дії [11].

На думку А.А. Коваль, фактичними підставами виступають дві обставини: обмеження конституційних прав людини допустиме лише через неможливість отримати відомості про злочин та особу, яка його вчинила в інший спосіб; негласні слідчі дії, які передбачені ст.ст. 260-264 (у частині дій, що проводяться на підставі ухвали слідчого судді), 267, 269-274 проводяться, якщо вчинений злочин тяжкий чи особливо тяжкий. Юридичними підставами автор вважає рішення слідчого, прокурора, слідчого судді про проведення негласних слідчих дій у межах їхньої компетенції в передбачених законом випадках [12].

Ю.М. Мирошниченко зазначає, що під час розв'язання цього питання необхідно враховувати специфіку слідчих дій, проведення яких вимагає попереднього дозволу слідчого судді. Річ у тім, що слідча дія - це комплекс взаємопов'язаних, послідовних операцій із визначення мети й прийняття тактичного рішення, підготовки й безпосереднього проведення слідчої дії, фіксації їі результатів. Слідчий суддя не є суб'єктом цього виду діяльності, його функція обмежується перевіркою наявності підстав для проведення негласних слідчих дій певної категорії. Тому нам здається корисним розрізняти підстави провадження негласних слідчих дій і підстави ухвалення рішення про дозвіл на їх проведення.

Юридичними підставами такого рішення $\epsilon$ сукупність сутнісних умов, з якими закон пов'язує можливість проведення негласних слідчих дій. Фактичними підставами для ухвалення рішення щодо проведення негласних слідчих дій $є$ отримані з належних процесуальних джерел відомості (фактичні дані, докази), які підтверджують наявність зазначених умов [6, с. 119].

У своїй дисертаційній роботі О.В. Соколов поділяє підстави проведення процесуальних дій (у тому числі негласних слідчих дій) на три групи: матеріально-правові, процесуальні й фактичні [13, с. 89]. Матеріально-правовою підставою проведення негласних слідчих дій $\epsilon$ ступінь тяжкості злочину, щодо якого здійснюється розслідування в рамках конкретного кримінального провадження. Ст. 300 КПК обмежує сферу застосування негласних слідчих дій, проведення яких у процесі розслідування кримінальних проступків не допускається.
Доцільно зазначити думку І.В. Рогатюк, що зазначає, що практиці відомі ситуації, коли на початку досудового розслідування «вбачалися» ознаки тяжкого злочину, а після проведення негласних слідчих дій такі діяння перекваліфіковувались на менш тяжкі. Тому виникає питання допустимості у цьому кримінальному провадженні отриманих доказів - протоколів негласних слідчих дій, якими зафіксовано обставини кримінального правопорушення середньої тяжкості. На погляд вказаного науковця, правильним у цій ситуації рішенням буде не враховувати результати негласних слідчих дій у процесі прийняття рішення у такому кримінальному провадженні [14, с. 62].

Процесуальною підставою здійснення негласних слідчих дій $\epsilon$ відповідне рішення, прийняте суб'єктом кримінального провадження в межах його компетенції [15, с. 429]. При цьому М.В. Багрій та В.В. Луцик слушно зазначають, що відповідно до п. 1.9. Інструкції про негласні слідчі дії процесуальними документами щодо проведення негласних слідчих дій є постанови, клопотання, доручення, протоколи уповноваженого співробітника (працівника) оперативного підрозділу, слідчого, прокурора, а також ухвали слідчого судді. Це широке трактування законодавцем процесуальних документів.

У вузькому розумінні процесуальних документів, які $\epsilon$ процесуальною підставою для проведення негласних слідчих дій, ними варто вважати постанову слідчого, прокурора (у випадках, коли вони уповноважені законом прийняти таке рішення) або ухвалу слідчого судді [16, с. 53].

Фактичними підставами проведення негласних слідчих дій $є$ відомості про реальну можливість отримати в результаті їх здійснення докази, які мають значення для кримінального провадження [15, с. 430].

Аналізуючи правове регулювання надання дозволу на проведення негласних слідчих дій, варто зазначити, що клопотання слідчого, прокурора про надання дозволу на проведення негласної слідчої дії має відповідати вимогам ч. 2 ст. 248 КПК [1]. До клопотання слідчого, прокурора додається витяг з Єдиного реєстру досудових розслідувань щодо кримінального провадження, в рамках якого подається клопотання.

На думку Ю.В. Меркулової та І.С. Казарян, ч. 2 ст. 248 КПК доцільно доповнити положенням, що для підтвердження необхідності проведення негласної слідчої (розшукової) дії на вимогу слідчого судді надаються матеріали кримінального провадження [5, с. 110]. На надання таких мате- 
ріалів вказано у п. 2.2 Інструкції «Про організацію проведення негласних слідчих (розшукових) дій та використання їх результатів у кримінальному провадженні». Також у п. 1.10.1 цієї Інструкції зазначено, що слідчому судді необхідно надати відомості, незалежно від виду негласної слідчої (розшукової) дії, отримані в процесі досудового розслідування, що підтверджують неможливість одержання відомостей про злочин чи особу, яка його вчинила, в інший спосіб [17].

Так, відповідно до ч.ч. 3,4 ст. 248 КПК, слідчий суддя має постановити ухвалу про дозвіл на проведення негласної слідчої (розшукової) дії, якщо слідчий, прокурор доведе наявність достатніх підстав вважати, що: 1) вчинений злочин відповідної тяжкості; 2) під час проведення негласної слідчої (розшукової) дії можуть бути отримані докази, які самостійно або в сукупності з іншими доказами можуть мати суттєве значення для з'ясування обставин злочину або встановлення осіб, які вчинили злочин [1].

Зі змісту ч. 3 ст. 248 КПК зрозуміло, що слідчий суддя має постановити ухвалу про відмову в надані дозволу на проведення негласної слідчої дії, якщо слідчий, прокурор не доведе вищевказані обставини. Очевидно, що таку ухвалу слідчий суддя зобов'язаний постановити і у тому випадку, якщо клопотання про надання дозволу на проведення негласної слідчої дії не відповідає встановленим вимогам. Оскільки про підстави та порядок прийняття таких рішень у ст. 248 КПК не вказано, вважаємо необхідним доповнити їі відповідним положенням [5, с. 110].

Аналізуючи склад осіб, які приймають рішення про проведення негласних слідчих дій, А.В. Шило зазначає, що одним із найбільш дискусійних питань, що висвітлюється у науковій літературі, $\epsilon$ суб'єктний склад осіб, уповноважених на прийняття рішення про проведення негласних слідчих дій та на їх виконання. Зокрема, досить спірною видається роль слідчого у проведенні негласних слідчих дій, можливість чого передбачена чинним КПК [8, с. 30-31].

3 цього приводу А.А. Коваль вказує: «Надання слідчому права на проведення негласних слідчих дій $\epsilon$ досить вагомим кроком у бік забезпечення прав людини, тому що для слідчого захист особи, суспільства та держави від кримінальних правопорушень, охорона прав, свобод та законних інтересів учасників кримінального провадження, а також забезпечення швидкого, повного та неупередженого розслідування $\epsilon$ основним завданням, тоді як для оперативних підрозділів розкриття і розслідування злочину $є$ однією з функцій, до того ж не головною» [18, с. 241].

Доречним у розрізі досліджуваної наукової проблематики $\epsilon$ зауваження М.В. Корнієнко та В.М. Тертишник, що регламентація негласних слідчих (розшукових) дій здійснюються без належної системності і логічності, часто створюючи штучну конкуренцію правових норм, а окремі інститути негласних слідчих (розшукових) дій ще не отримали необхідної та досконалої процесуальної форми, яка б слугувала достатньою гарантією отримання надійних доказів і належного захисту прав і свобод людини, реалізацією визнаних (підтримуваних і неухильно забезпечуваних) у практиці ЄСПЛ принципів юридичної визначеності та пропорційності [19, с. 65]. Тому доцільно підтримати А.А. Коваль, яка говорить, що забезпечення прав людини під час проведення негласних слідчих дій безпосередньо залежить від ефективності кримінальних процесуальних норм, що регламентують правовий порядок їх провадження [20].

Висновки. Таким чином, враховуючи вищевикладене, варто зазначити, що проблематика правового регулювання проведення негласних слідчих дій нині потребує уточнення та удосконалення. Дискусійними питаннями, які потребують подальшого вирішення, $\epsilon$ уточнення підстав та порядку прийняття рішення слідчим суддею про дозвіл чи відмову у проведенні негласних слідчих дій слідчому, прокурору, наукове дослідження та уточнення участі та взаємодії слідчого 3 оперативними підрозділами в процесі проведення негласних слідчих дій. Вирішення вказаних завдань дасть змогу сформувати обґрунтовані пропозиції удосконалення діючого законодавства у сфері правового регулювання реалізації негласних слідчих дій та прийняття рішення про їх дозвіл чи відмову, а також підвищить результативність використання матеріалів, отриманих під час проведення негласних слідчих дій у процесі проведення кримінального провадження.

\section{Література}

1. Кримінальний процесуальний Кодекс України. Відомості Верховної Ради України (ВВР). 2013. № 9-10, № 11-12, № 13. Ст. 88. URL: https://zakon. rada.gov.ua/laws/show/4651-17 (дата звернення: 05.11.2020).

2. Конституція України. Відомості Верховної Ради України (ВBP). 1996. № 30. СТ. 141. URL: https:// zakon.rada.gov.ua/laws/show / 254\%D0\%BA/ 96 \%D0\%B2\%D1\%80\#Text (дата звернення: 05.11.2020). 
3. Грошевий Ю.М., Стахівський С.М. Докази та доказування у кримінальному процесі. Київ : КНТ, 2006. 272 c.

4. Колесник В.А. Негласні слідчі (розшукові) дії: кримінально-процесуальні та криміналістичні аспекти підготовки і проведення : наук.-практ. посібник. Київ : «Прецедент», 2014. 135 с.

5. Меркулова Ю.В., Казарян І.С. Нормативно-правове регулювання та психологічні аспекти прийняття слідчим суддею рішення щодо надання дозволу на проведення негласних слідчих (розшукових) дій. Південноукраїнський правничий часопис. 2018. № 4. Т. 2. С. 108-112.

6. Мирошниченко Ю. Негласні слідчі (розшукові) дії: підстави проведення. Правова позиція. 2019. № 2 (23). С. 117-121.

7. Сергєєва Д.Б. Проблемні питання постановлення ухвали про проведення негласних слідчих (розшукових) дій. Вісник Чернівецького факультету Національного університету «Одеська юридична академія». 2014. № 1. С. 177-186.

8. Шило А.В. Використання в кримінальному провадженні відомостей, отриманих у результаті проведення негласних слідчих (розшукових) дій : дис. ... канд. юрид. наук : 12.00.09. Харків, 2019. 233 с

9. Колесник В.А. Проблемні питання проведення негласних слідчих (розшукових) дій та їх учасників. Кримінальне провадження: новаціі процесуальної теорії та криміналістичної практики : матеріали міжнар. наук.-практ. конф., Сімферополь, 18-19 квітня 2013 р. Сімферополь, 2013. C. 80-82.

10. Іваненко І. Негласні слідчі (розшукові) дії: окремі аспекти правозастосування. Слово Національної школи суддів України. 2013. № 3 (4). С. 64-70.

11. Сергєєва Д.Б. Правові та фактичні підстави провадження негласних слідчих (розшукових) дій. Вісник кримінального судочинства. 2017. № 4. C. 56-65.

12. Коваль А.А. Гарантії захисту конституційного права людини на приватність при проведенні окремих негласних слідчих (розшукових) дій. Ольвійський форум - 2014 : стратегії країн Причорноморського регіону в геополітичному просторі : міжнар. наук.-практ. конф., Миколаїв, 4-7 червня 2014 р. Миколаїв, 2014. С. 63-65.
13. Соколов О.В. Виконання оперативними підрозділами доручень слідчого, прокурора про проведення негласних слідчих (розшукових) дій : дис. ... канд. юрид. наук : 12.00.09. Харків, 2019. 233 с.

14. Рогатюк І.В. Правові та організаційні засади проведення негласних слідчих (розшукових) дій. Юридичний часопис Національної академії внутрішніх справ. 2015. № 1. С. 52-63.

15. Кримінальний процес : підручник / Нац. ун-т «Юрид. акад. України ім. Ярослава Мудрого»; за ред. В.Я. Тація та ін. Харків : Право, 2013. 824 с.

16. Багрій М.В., Луцик В.В. Процесуальні аспекти негласного отримання інформації: вітчизняний та зарубіжний досвід : монографія. Харків : Право, 2017. 376 c.

17. Про затвердження Інструкції «Про організацію проведення негласних слідчих (розшукових) дій та використання їх результатів у кримінальному провадженні»: наказ Генеральної прокуратури України, Міністерства внутрішніх справ України, Служби безпеки України, Адміністрації Державної прикордонної служби України, Міністерства фінансів України, Міністерства юстиції України від 16 листопада 2012 р. № 114/1042/516/1199/936/1681/51. URL: https:// zakon.rada.gov.ua/laws/show/v0114900-12\#Text (дата звернення: 12.11.2020).

18. Коваль А.А. Актуальні проблеми забезпечення конституційних прав людини при провадженні негласних слідчих (розшукових) дій. Форум права. 2014. № 1. С. 238-242.

19. Корнієнко М.В., Тертишник В. М. Доктринальні проблеми інституту негласних слідчих (розшукових) дій. Міжнародний науковий журнал «Верховенство права». 2017. № 1. С. 95-101.

20. Коваль А. Напрямки удосконалення механізму забезпечення прав людини при проведенні негласних слідчих (розшукових) дій. International scientific journal «Internauka» Series : Juridical Sciences. URL: http://www.inter-nauka.com/magazine/law (дата звернення: 12.11.2020).

Скрябін О. М., доктор юридичних наук, доцент, доцент кафедри кримінального права, процесу та криміналістики Класичного приватного університету 